\title{
Pengaruh Biochar Sekam Padi yang Diperkaya Hara dan Ketebalan Mulsa Terhadap Pertumbuhan dan Hasil Selada Darat (Lactuca sativa, L.)
}

\author{
Kristina Irna Sari Naikofi a dan Eduardus Yosef Neonbeni ${ }^{\mathrm{b}}$ \\ a Fakultas Pertanian, Universitas Timor, Kefamenanu, TTU - NTT, Indonesia. \\ ${ }^{b}$ Fakultas Pertanian, Universitas Timor, Kefamenanu, TTU - NTT, Indonesia.
}

\section{Article Info}

\section{Article history:}

Received 12 Maret 2016

Received in revised form 27 Juni 2016

Accepted 20 September 2016

Keywords:

Biochar Sekam Padi

Mulsa Alang-Alang

Selada Darat

Lactuca sativa, L

\section{Pendahuluan}

Selada (Lactuca sativa L.) merupakan sayuran daun yang berumur pendek (30 hari), dan dapat ditanam di dataran tinggi atau dataran rendah (Edi dan Yusri, 2010). Sayuran ini biasa dikonsumsi sebagai lalap mentah, salad, dan hamburger (Sastradiharja, 2011), atau dijadikan penghias hidangan karena daunnya yang hijau segar dan bergerigi atau berombak. Kandungan mineral selada cukup tinggi termasuk fosfor, zat besi, kalsium, kalium, natrium, magnesium, vitamin A, B dan $\mathrm{C}$ sehingga berkhasiat dalam menjaga keseimbangan cairan elektrolit tubuh manusia (Wahyudi, 2005).

Di lahan kering penanaman selada di tanah Vertisol pada musim hujan dapat menjamin ketersedian air, namun kondisi air yang berlebihan dan kondisi tanah Vertisol yang mengembang, dapat menghambat perkembangan dan respirasi akar selada yang dangkal dan halus. Oleh karena itu, upaya untuk memperbaik aerasi tanah Vertisol agar dapat ditanami selada pada musim hujan perlu dilakukan

Biochar sekam padi yang diperkaya hara merupakan biochar sekam padi yang direndam di dalam larutan hara. Luas dan muatan permukaan biochar yang tinggi diproyeksikan dapat meretensi hara selama perendamannya di dalam larutan hara. Ketika biochar sekam diberikan ke dalam tanah diharapkan unsurunsur hara yang telah diikat tersebut dilepaskan secara perlahan-lahan ke dalam tanah dan dapat diserap oleh tanaman. Hal tersebut didukung oleh hasil-hasil penelitian bahwa pemberian biochar ke dalam tanah dapat menurunkan kehilangan hara (Major et al., 2012). Sebagai contoh, pemberian biocha campuran kayu keras $20 \mathrm{~g} / \mathrm{kg}$ yang dikombinasikan dengan pupuk kandang babi $5 \mathrm{~g} / \mathrm{kg}$ pada tanah Molisol menekan pelindian total $\mathrm{N}$ dan total $\mathrm{P}$ terlarut masing masing $11 \%$ and $69 \%$ (Laird et al., 2010a). Biochar juga memiliki bobot volume yang rendah sehingga ketika diberikan ke dalam tanah dapat menurunkan bobot volume tanah dan memperbaiki kapasitas infiltrasi. Hasil penelitian sebelumnya menunjukkan penurunan bobot volume tanah setelah pemberian biochar karena rendahnya bobot volume biochar (Laird et al., 2010b; Oguntunde et al., 2008) dan penurunan bobot volume tersebut dapat meningkatkan laju infiltras (Franzluebbers, 2002). Aplikasi biochar di tanah Vertisol pada musim hujan diharapkan dapat memperbaiki aerasi dan memperkaya hara tanaman. Selain itu, mulsa juga dapat berperan ganda ketika diaplikasikan pada musim hujan, yakn menjaga fluktasi suhu tanah, mengurangi pemadatan tanah dan menutup permukaan tanah sehingga menghindari daun-daun selada dari percikan tanah yang boleh jadi membawa-serta soil-born pest, disamping fungsi-fungsi lainnya

Permasalahannya adalah belum tersedia informasi tentang takaran biochar sekam padi yang diperkaya hara dan ketebalan mulsa yang tepat yang dapa meningkatkan pertumbuhan dan hasil selada, sehingga tujuan dari penelitian ini adalah untuk mengetahui takaran biochar sekam padi yang diperkaya hara bagi tanaman selada darat jika dikombinasikan dengan pemberian mulsa.

\section{Metode}

Penelitian telah dilaksanakan pada Desember 2015 sampai Februari 2016 di kebun percobaan Fakultas Pertanian, Universitas Timor, Kelurahan Sasi, Kecamatan Kota Kefamenanu, Kabupaten TTU. Rancangan percobaan yang diterapkan pada penelitian ini adalah rancangan acak lengkap berpola faktorial, yang terdiri dari 2 faktor yaitu : faktor pertama takaran biochar sekam padi yang diperkaya terdiri dari 3 aras yaitu 0,2 dan 4\%; faktor kedua adalah ketebalan mulsa terdiri dari 3 aras yaitu 0,2 dan $4 \mathrm{~cm}$ selanjutnya disusun secara acak $3 \mathrm{x}$ 3 yang diulang sebanyak 3 kali.

Variabel yang diamati dalam penelitian ini antara lain sebagai berikut: tinggi tanaman, jumlah daun, berat segar berangkasan, berat kering berangkasan dan berat kering akar. Data hasil pengamatan kemudian dianalisis dengan menggunakan sidik ragam (Anova) rancangan acak lengkap. Rata-rata perlakuan selanjutnya diuji lanjut dengan menggunakan Tukey test atau HSD dengan tingkat signifikasi 5\% sesuai petunjuk Gomez dan Gomez, (1995). Analisis data menggunakan program SAS 9.1 .

\section{Hasil dan Pembahasan}

3.1 Tinggi Tanaman

Aplikasi biochar sekam padi yang dikombinasikan dengan mulsa berinteraksi secara positif $(\mathrm{P}<0.05)$ dalam mempengaruhi tinggi tanaman selada Tinggi tanaman selada yang dihasilkan secara signifikan lebih tinggi dari pada kontrol. Tinggi tanaman yang tertinggi hingga pertumbuhan vegetatif maksimum adalah $8,22 \mathrm{~cm}$ yang diperolah dari kombinasi biochar $2 \%$ dan mulsa $2 \mathrm{~cm}$. Hasil penelitian dapat di lihat pada Gambar 1 .

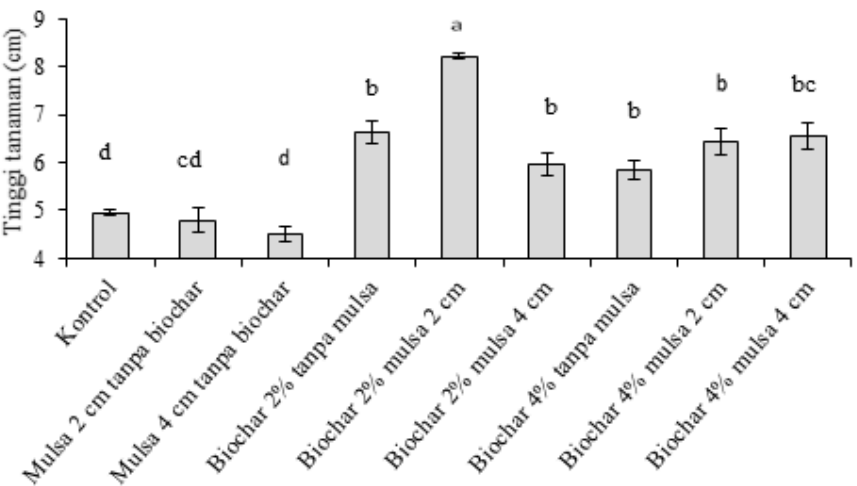

Keterangan: Rerata perlakuan yang diikuti huruf yang sama berbeda tidak nyata berdasarkan uji tukey $\alpha=5 \%$.

Gambar 1. Tinggi Tanaman 35 Hari Setelah Tanam

\subsection{Jumlah Daun}

Aplikasi biochar sekam padi yang dikombinasikan dengan mulsa berinteraksi secara positif $(\mathrm{P}<0.05)$ dalam mempengaruhi jumlah daun selada Jumlah helai daun yang dihasilkan secara signifian lebih banyak dari pada kontrol. Jumlah helai daun terbanyak hingga pertumbuhan vegetatif maksimum adalah 7 helai diperoleh dari komibinasi biochar $2 \%$ dan mulsa $2 \mathrm{~cm}$. Hasil penelitian dapat di lihat pada Gambar 2.

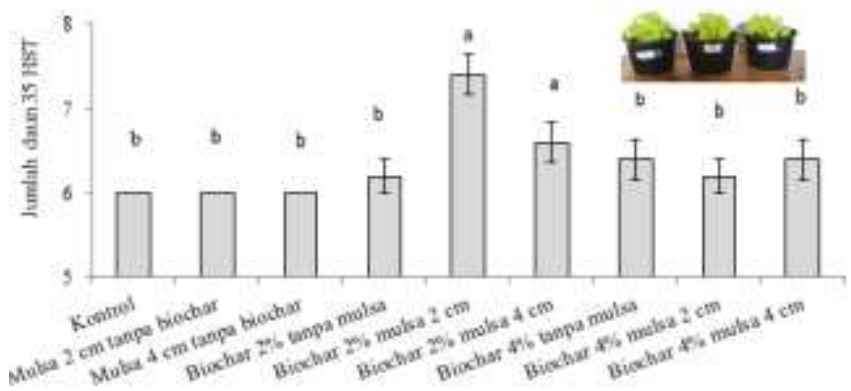

Keterangan: Rerata perlakuan yang diikuti huruf yang sama berbeda tidak nyata berdasarkan uji tukey $\alpha=5 \%$

Gambar 2. Jumlah Daun 35 Hari Setelah Tanam

\subsection{Berat Segar Trubus}

Aplikasi biochar sekam padi yang dikombinasikan dengan mulsa berinterkasi secara nyata positif $(\mathrm{P}<0.05)$ dalam mempengaruhi berat segar trubus tanaman selada. Berat segar trubus yang terbanyak hingga pertumbuhan 
vegetatif maksimum adalah 22,16 yang diperoleh dari kombinasi biochar $2 \%$ dan mulsa $2 \mathrm{~cm}$. Hasil penelitian dapat di lihat pada Gambar 3 .

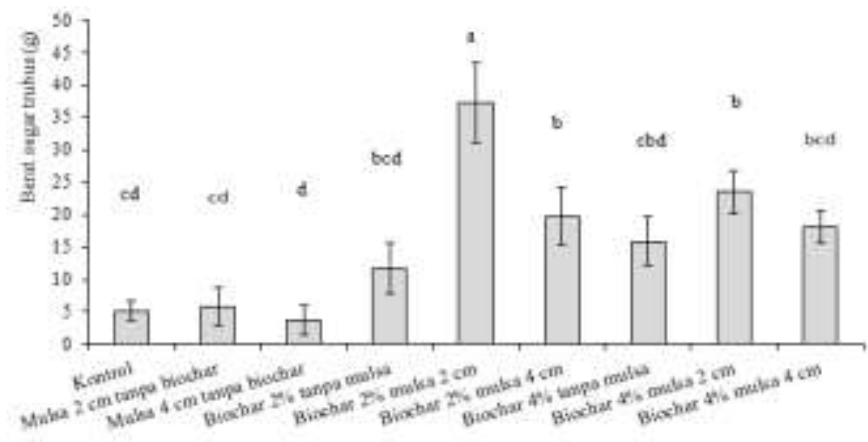

Keterangan: Rerata perlakuan yang diikuti huruf yang sama berbeda tidak nyata berdasarkan uji tukey $\alpha=5 \%$.

Gambar 3. Berat Segar Trubus

\subsection{Berat Kering Trubus}

Aplikasi biochar sekam padi dan yang dikombinasikan dengan mulsa berinterkasi secara nyata positif $(\mathrm{P}<0.05)$ dalam mempengaruhi berat kering trubus tanaman selada. Berat kering trubus yang tertinggi hingga pertumbuhan vegetatif maksimum adalah 1,44 yang diperoleh dari kombinasi biochar $2 \%$ dan mulsa $2 \mathrm{~cm}$. Hasil penelitian dapat di lihat pada Gambar 4 .

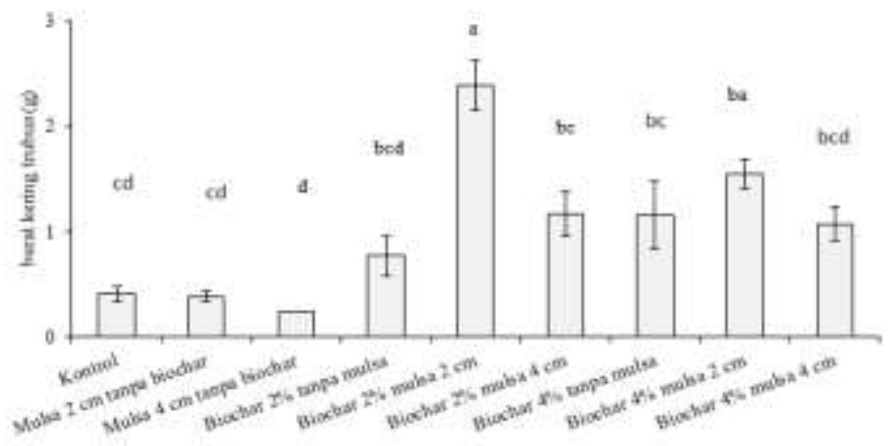

Keterangan: Rerata perlakuan yang diikuti huruf yang sama berbeda tidak nyata berdasarkan uji tukey $\alpha=5 \%$.

Gambar 4. Berat Kering Trubus

\subsection{Berat Kering Akar}

Aplikasi biochar sekam padi yang dikombinasikan dengan mulsa berinterkasi secara positif $(\mathrm{P}<0.05)$ dalam mempengaruhi berat kering akar tanaman selada. Berat kering akar yang terberat hingga pertumbuhan vegetatif maksimum adalah $0,61 \mathrm{~g}$ yang diperoleh dari kombinasi biochar $2 \%$ dan mulsa $2 \mathrm{~cm}$. Hasil penelitian dapat di lihat pada Gambar 5 .

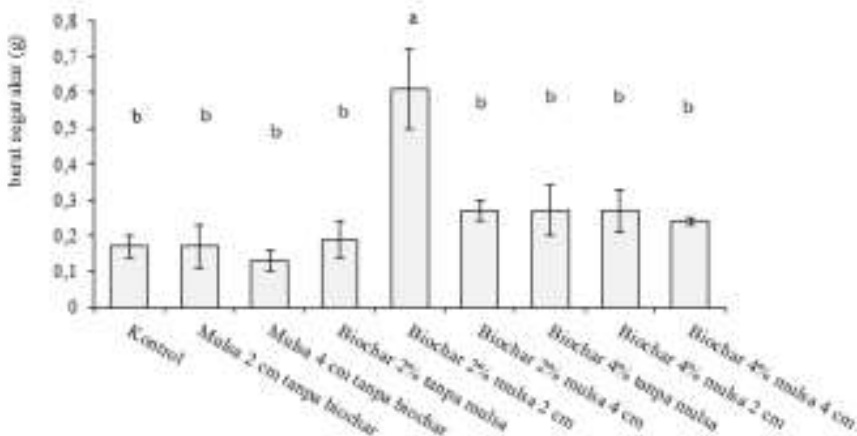

Keterangan: Rerata perlakuan yang diikuti huruf yang sama berbeda tidak nyata berdasarkan uji tukey $\alpha=5 \%$.

Gambar 5. Berat Kering Akar

\subsection{Pembahasan}

Tanah vertisol dengan pori mikro yang banyak menyebabkan aerasinya sangat kurang, apabila tidak diberikan biochar akan menghambat penyerapan hara oleh akar dan pertumbuhan tanaman. Ini terbukti pada rerata berat segar akar pada control (tanpa biochar) yang lebih rendah dibandingkan perlakuan $2 \%$ dan $4 \%$ biochar. Demikian pula bila pemberian biochar yang dikombinasikan dengan mulsa juga menunjukkan bahwa pemberian biochar dengan mulsa menyebabkan berat kering akar lebih tinggi dari pada perlakuan kombinasi tanpa arang dengan semua taraf mulsa $(0,2$ dan $4 \mathrm{~cm})$.
Demikian pula pemberian mulsa dengan ketebalan lebih dari $2 \mathrm{~cm}$ menyebapkan aerasi dalam tanah tidak baik, berdampak pada respirasi akar yang tidak baik pula. Mulsa yang lebih tebal dari $2 \mathrm{~cm}$ menyebabkan kelembaban tanah semakin tinggi, sekalipun diberikan bersama biochar yang lebih dari $2 \%$ justeru semakin mengganggu pertumbuhan akar dan menyebapkan pertumbuhan serta produksi tanaman tidak maksimal.

Pemberian arang dan mulsa memberikan pertumbuhan tanaman yang paling baik berupa tinggi tanaman $(8,22 \mathrm{~cm})$, jumlah daun yang cukup banyak ( 7 helai), berat segar trubus $(23,49)$, berat kering tanaman $(2,39)$, berat kering akar $(0,61)$. Pemberian biochar sekam padi dan mulsa meningkatkan pertumbuhan dan hasil selada dibandingkan dengan perlakuan yang lain. Hal ini disebabkan pemberian Biochar 2\% lebih optimum dalam memperbaiki porositas tanah vertisol, sehingga perakaran tanaman dapat tumbuh dan berkembang dengan baik, penyerapan air dan unsur hara pun menjadi lebih baik untuk pertumbuhan dan produksinya.

\section{Simpulan}

Pemberian biochar dan mulsa meningkatkan pertumbuhan dan hasil selada dibandingkan dengan kontrol. Biochar sekam padi 2\% dan mulsa alang-alang 2 $\mathrm{cm}$ memberikan pertumbuhan dan hasil terbaik bagi selada

\section{Pustaka}

Edi dan Yusri. 2010. Budidaya Sawi Hijau. Jurnal Agrisistem. Balai Pengkajian Teknologi Pertanian Jambi. Jambi.

Franzluebbers, A. J. 2002 . Water infiltration and soil structure related to organic matter and its stratification with depth. Soil \& Tillage Research $66: 197$ 205.

Gomez, K. A. dan A. A. Gomes. 1995. Prosedur Statistik untuk Penelitian Pertanian. Edisi ke 2. Jakarta:UI Press.

Laird, D., P. Fleming, B. Wang, R. Horton, \& D. Karlen. 2010a. Biochar impact on nutrient leaching from a Midwestern agricultural soil. Geoderma, 158 : 436-442.

Laird, D., P. Fleming, D. Davis, R. Horton, B. Wang, \& D. L. Karlen. 2010b. Impact of biochar amendments on the quality of a typical Midwestern agricultural soil. Geoderma, 158 : 443-449.

Major, J. 2010. Soil Improvement from Application of Biochar. International Biochar Inititive. IBI Research Summaries are intended to provide answers about biochar science for the general public. Soil Improvement. 8 June 2010.

Oguntunde, P. G., B. J. Abiodun, A. E. Ajayi, \& N. van de Giesen. 2008. Effects of charcoal production on soil physical properties in Ghana. Journal of Plant Nutrition and Soil Science, 171: 591-596. 